\title{
Bioactivity of carotenoid produced by soft coral symbiotic microorganisms from Panjang and Karimunjawa Island, Central Java, Indonesia
}

\author{
LIA KUSMITA ${ }^{1,2, \vartheta}$, HANDUNG NURYADI ${ }^{3}$, PRASTYO ABI WIDYANANTO ${ }^{4}$, SAKTI MUCHLISSIN $^{4}$, \\ AGUS SABDONO ${ }^{4}$, AGUS TRIANTO ${ }^{4,5}$, OCKY KARNA RADJASA ${ }^{4,6}$ \\ ${ }^{1}$ Coastal Resources Management, Faculty of Fisheries and Marine Sciences, Universitas Diponegoro. Jl. Prof. H. Soedarto, S.H., Tembalang, Semarang \\ 50275, Central Java, Indonesia. Tel./fax.: +62-24-7474698, "email: lia_kusmita@yahoo.com \\ ${ }^{2}$ STIFAR "Yayasan Pharmasi Semarang". Jl. Letjen Sarwo Edie Wibowo Km. 1, Pedurungan, Semarang 50192, Central Java, Indonesia \\ ${ }^{3}$ Graduate School of Engineering and Science, University of The Ryukyus. Senbaru, Nishihara, Okinawa 903-0213, Japan \\ ${ }^{4}$ Department of Marine Science, Faculty of Fisheries and Marine Science, Universitas Diponegoro. Jl. Prof. H. Soedarto, S.H., Tembalang, Semarang \\ 50275, Central Java, Indonesia \\ ${ }_{5}^{5}$ Marine Natural Products Laboratory, Faculty of Fisheries and Marine Science, Universitas Diponegoro. Jl. Prof. H. Soedarto, S.H., Tembalang, \\ Semarang 50275, Central Java, Indonesia \\ ${ }^{6}$ Tropical Marine Biotechnology Laboratory, Faculty of Fisheries and Marine Science, Universitas Diponegoro. Jl. Prof. H. Soedarto, S.H., Tembalang, \\ Semarang 50275, Central Java, Indonesia
}

Manuscript received: 17 November 2020. Revision accepted: 13 January 2021.

\begin{abstract}
Kusmita L, Nuryadi H, Widyananto PA, Muchlissin S, Sabdono A, Trianto A, Radjasa OK. 2021. Bioactivity of carotenoid produced by soft coral symbiotic microorganisms from Panjang and Karimunjawa Island, Central Java, Indonesia. Biodiversitas 22: 732-740. The diversity of soft corals is more varied in waters. One of the characteristics of soft corals is the production of secondary metabolites, i. i.e. carotenoids. Carotenoids are phytonutrients found in the cells of a wide variety of plants, algae, and bacteria as secondary metabolic compounds with antioxidant functions. Carotenoid biosynthesis is strongly influenced by the environment in which the producing organism grows. This study was aimed to uncover the antioxidant and anti-ultraviolet activities of carotenoids produced by soft coral symbiotic microorganisms in the waters surrounding the Panjang and Karimunjawa Islands in the North Java Sea, Indonesia. The parameters observed included water quality, antioxidant activity, and anti-ultraviolet activity. The results indicated that the water quality at Panjang Island did not meet quality standards (including salinity, visibility, dissolved oxygen, ammonia, and nitrate) while that at Karimunjawa did. The diversity of soft corals was more varied at Karimunjawa Island than at Panjang Island. In contrast to the bioactivity, the carotenoid extracts from the Panjang Island soft coral symbiotic microorganisms showed higher activity than those from Karimunjawa Island microorganisms. The highest antioxidant activity was found in the bacterial isolate 19.PP.Sc1.6 from Panjang Island and was identified based on the 16S rRNA gene as Virgibacillus salarius, with $99 \%$ similarity.
\end{abstract}

Keywords: Carotenoids, Karimunjawa island, Panjang island, seawater quality, symbiotic microorganisms

\section{INTRODUCTION}

Carotenoids are yellow-orange to red-colored pigments (Shetty et al. 2017). They can be found in terrestrial and marine organisms, and even in microorganisms (Galasso et al. 2017). Carotenoids have important functions in the processes of photosynthetic. They absorb light energy in the range of $300-600 \mathrm{~nm}$, beyond the absorption range of chlorophyll. The light energy is then transferred to chlorophyll to drive other photosynthetic processes. Moreover, carotenoids photoprotect photosynthetic organisms from harmful excess light during the lightharvesting process of photosynthesis (Vilchez et al. 2011).

Marine carotenoids are important bioactive compounds with physiological activities related to the prevention of degenerative diseases (Riccioni et al. 2011). The exploitation of symbiotic bacteria as a source of novel bioactive molecules, including carotenoids, is considered to be in its early stages. Among the unusual niches of novel microbes are marine invertebrates, one of which is soft coral. As marine diversity reflects chemical diversity, the isolation of under-exploited bacterial symbionts from marine invertebrates offers a great opportunity for discovering novel bioactive pigments. By screening these compounds against various disease targets with significant impact, there is a strong potential for the treatment of diseases. In particular, the diversity of pigment-producing microorganisms offers a great opportunity for the discovery of novel carotenoids (Puspasari et al. 2011; Radjasa et al. 2011).

Different environments also affect carotenoid production. Among the natural carotenoids, more than 250 types originate from the sea (Maoka 2011). Marine organisms generally produce carotenoids with an interesting diversity of structures and very strong bioactivity (Ibrahim 2012; Galasso et al. 2017). Even the microorganisms associated with marine organisms produce carotenoids that have the same or similar activity levels as those of their hosts (Murti et al. 2016). 
Several studies on the bioactivity of carotenoid pigments in the symbiotic microorganisms associated with marine organisms have been conducted (Nugraheni et al. 2010; Kusmita et al. 2017; Sibero et al. 2019). However, no studies have yet explored the relationship between seawater quality and carotenoid production. Carotenoids, as secondary metabolic compounds, defend their producing organisms within their environments (Amri et al. 2018). Secondary metabolites are produced in response to interactions between the organism and the environment. They possess antibacterial, anti-ultraviolet (UV) radiation, and antifouling mechanisms, and act as an organism's defense against predators (Yang et al. 2018).

The environment is one of the key factors that influence the secondary metabolite content of organisms. Panjang and Karimunjawa Islands have different characteristics owing to the water conditions. The waters of Panjang Island have been affected by human activities on Java Island (Farantika et al. 2020), so that the conditions are more polluted than those around Karimunjawa Island. Pollution can spur the production of secondary metabolites in organisms that live in the polluted environment (Ramakrishna and Ravishankar 2011).

Several studies have been conducted previously on environmental pressure that increasing the production of secondary metabolites (Yang et al. 2018; Isah 2019). Environmental pressure facilitates the production of metabolites that stimulate survival in that environment. Thus, the produced secondary metabolites have higher potential bioactivity. Based on the background mentioned above, this study compared the antioxidant and anti-UV activity of carotenoids from soft coral-associated microorganisms collected at two geographically different sites, Panjang and Karimunjawa Islands, in the North Java Sea, Indonesia.

\section{MATERIALS AND METHODS}

\section{Measurement of ecological parameters}

The measurement of ecological parameters was conducted simultaneously with soft coral sampling at each observation location. The ecological parameters, including salinity, $\mathrm{pH}$, temperature, brightness, dissolved oxygen (DO), biochemical oxygen demand (BOD5), total suspended solids, nitrate concentration, and ammonia concentration, were measured in situ. The measurements of ecological parameters on Panjang Island were made during the rainy season.

\section{Collection and identification of soft corals}

The soft coral samples were collected from Panjang Island and Karimunjawa National Park, Jepara, Indonesia by SCUBA diving with depth $\pm 1 \mathrm{KM}$ (Figure 1 ). The colonies of the soft coral samples were documented by taking in situ pictures with a Canon S50 underwater camera. Small sample pieces of the soft coral were cut off, placed in sterile plastic bags containing seawater, stored in a cooler box (Sabdono et al. 2015), and immediately brought to the laboratory for identification and symbiotic bacterial isolation. The morphological characteristics of all soft coral samples were observed based on growth shape, texture, colony color, and sclerite, and the samples were then identified as per available standard literature (Manuputty 2016).

\section{Isolation of soft coral symbiotic microorganisms}

The isolation of symbiotic microorganisms was conducted according to the method described by Kusmita et al. (2017) The soft coral tissues were placed into sterile Petri dishes that were partially filled with sterilized seawater. The surfaces of the soft coral tissues were cut away, and only the inside of the sample was used for microbial isolation. For bacterial isolation, a series of dilutions was conducted for all samples. From each petri dish, $10 \mathrm{~mL}$ of the sample was collected with a sterile pipette and placed into a flask containing $90 \mathrm{~mL}$ of sterilized seawater to obtain a $10^{-1}$ dilution. From the $10^{-1}$ dilution, $1 \mathrm{~mL}$ was moved into a tube containing $9 \mathrm{~mL}$ of sterile seawater to obtain a $10^{-2}$ dilution. This dilution process was repeated until a $10^{-5}$ dilution. A sample $(1 \mathrm{~mL})$ of each dilution series was collected, and placed into a sterile petri dish containing Zobell 2216E agar medium for bacterial isolation. Then, the Petri dishes were incubated at $30{ }^{\circ} \mathrm{C}$ for 2 days. Different colored bacterial colonies that grow on the surface of the agar media were separated by a streak method to obtain pure bacterial strains.

Fungal isolation was performed according to Kjer et al. (2010) using MEA media for the fungi and yeast isolations. The soft corals were cut into $1 \times 1 \mathrm{~cm}$ pieces, rinsed with sterile seawater, cleaned with $70 \%$ ethanol for surface sterilization, sprayed with sterilized marine water, and finally air-dried. Subsequently, the soft coral segments were placed in a petri dish containing marine MEA medium and incubated at room temperature for 7 days. For this step, an empty petri dish was used as an environmental control. Each fungus growing from a segment was compared to the control, and any fungus morphologically different from the control was transferred onto a new medium as a single fungal colony.

\section{Symbiotic microorganism pigment extraction}

Microbial strains with yellow-orange to red colony colorations were selected for pigment extraction. The strains were centrifuged IEC Centra MP4R at $6000 \mathrm{rpm}$ for 15 min to obtain bacterial or fungal pellets. The pellets were extracted using methanol after the pigment was removed from the microorganisms. The obtained extract was filtered with filter paper and the obtained pigment was dried using $\mathrm{N}_{2}$ gas.

\section{Antioxidant activity}

The crude pigment extracts were dissolved in methanol, and various concentration series were made. The blank was a mixture of $4 \mathrm{~mL}$ of $95 \%$ methanol and $1 \mathrm{~mL}$ of extract, while the sample solution consists of $4 \mathrm{~mL}$ of DPPH and 1 $\mathrm{mL}$ of extract. Both the blank and the sample were incubated for $30 \mathrm{~min}$ in a dark room. Subsequently, the absorbance was measured at a wavelength of $517 \mathrm{~nm}$ using a UV-visible spectrophotometer (Shimadzu, 1240). 




A

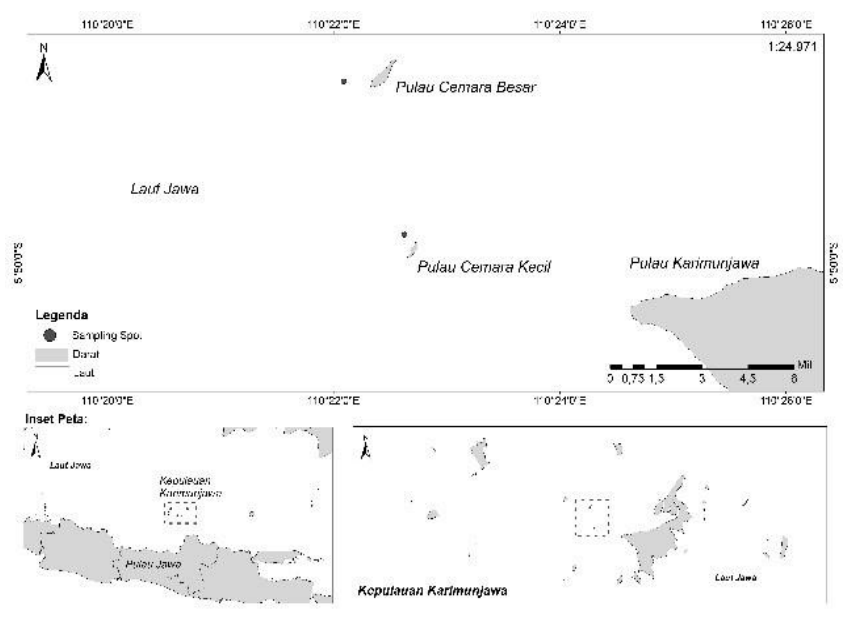

B

Figure 1. Location of sampling in Java Sea, Central Java, Indonesia. A. Panjang island; B. Karimunjawa island

The inhibitory activity was calculated using the following formula:

$$
\% \text { Inhibitory }=\frac{[D P P H]_{0}-[D P P H]_{S}}{[D P P H]_{0}} \times 100 \%
$$

Where, $[D P P H]_{0}=$ initial DPPH concentration and $[D P P H]_{s}=$ final DPPH concentration.

\section{Determination of sun protection factor}

The effectiveness of protection against UV light was determined in vitro with a UV-visible spectrophotometer. The sun protection factor (SPFs) of each crude pigment extract was determined at a concentration of $1000 \mathrm{ppm}$. The cuvette containing the pigment extract was inserted into a UV-visible spectrophotometer. The average absorbance of the tested solution was measured at intervals of $5 \mathrm{~nm}$ from $290-320 \mathrm{~nm}$. The absorbance results were recorded, and the SPF value was calculated using the Mansur equation (Mbanga et al. 2014):

$$
\mathrm{SPF}=\mathrm{CV} \times \sum_{290}^{320} E E(\lambda) \times I(\lambda) \times \operatorname{abs}(\lambda)
$$

Where, $\mathrm{CV}=$ correction value, $\mathrm{EE}=$ spectrum of erythema effect, I = spectrum of sun's intensity, and Abs = absorbance of sample.

\section{Molecular identification}

The selected bacterial strains with the highest activity were identified based on the 16S rRNA gene. The genomic DNA of the selected bacterial strain was extracted using the Quick-DNA Fungal/Bacterial Miniprep Kit (Zymo Research D6005) following the manufacturer's protocol. The PCR mixture was $1 \mu \mathrm{L}$ genomic DNA, $1 \mu \mathrm{L} 20$ pmol $27 \mathrm{~F}$ primer, $1 \mu \mathrm{L} 20$ pmol $1492 \mathrm{R}$ primer, $12.5 \mu \mathrm{L}$ My Taq



were initial denaturation at $95^{\circ} \mathrm{C}$ for $1 \mathrm{~min}$, followed by 35 cycles of $95{ }^{\circ} \mathrm{C}$ for $15 \mathrm{~s}, 52{ }^{\circ} \mathrm{C}$ for $15 \mathrm{~s}$, and $68^{\circ} \mathrm{C}$ for $45 \mathrm{~s}$. The quality of the PCR product was checked using $1 \%$ agarose gel. The good quality PCR product was sequenced by $1^{\text {st }}$ BASE laboratories (Malaysia) in both directions. The homology of the sequence was checked by comparing it with sequence data from GenBank (Radjasa et al. 2013). Subsequently, the sequence was aligned with 35 sequences from GenBank using the MUSCLE algorithm, and the alignment was then manually checked. A maximumlikelihood phylogenetic tree based on the 16S rRNA gene was constructed for phylogenetic analyses, using a GTR+G+I model with 1000 bootstrap replications in MEGA 7.0 (Kumar et al. 2016a). Bootstrap values $<50 \%$ were not shown. The sequence was deposited to GenBank under accession number LC537902.

\section{RESULTS AND DISCUSSION}

\section{Seawater quality measurement}

The quality of seawater used for marine life and other activities should ideally meet physical, chemical, and biological standards. Seawater quality values that exceed the maximum threshold for their designation can be classified as polluted waters (Hamuna et al. 2018). The ecological parameters results for the seawater from Panjang and Karimunjawa Islands are presented in Table 1.

\section{Soft corals and symbiotic microorganisms}

Soft corals were successfully collected from two geographically different sampling sites, Panjang and Karimunjawa Islands. Three genera of soft corals were collected from Panjang Island, Sinularia, Sarcophyton, and Lobophytum, and six genera were sampled from Karimunjawa Island, Stereonephthya, Sinularia, Lobophytum, Xenia, Cladiella, and Sarcophyton (Figure 2). 
Biodiversity of microorganism isolates from Karimunjawa and Panjang Island is presented in Table 2.

The microorganism isolates obtained from the Panjang Island waters were 32 bacteria and 18 fungi. Of these isolates, 10 bacteria and two fungi were found to produce carotenoids. Of the 32 bacterial isolates and 19 fungal isolates obtained from Karimunjawa Island, nine bacteria and four fungi produced carotenoids. Yellow symbiotic microorganisms from Panjang and Karimunjawa Islands in Figure 3.

Table 1. Ecological parameters of seawater

\begin{tabular}{lccc}
\hline \multicolumn{1}{c}{ Parameter } & Panjang island & Karimunjawa island & Quality standards \\
\hline Salinity $(\%)$ & 26 & 33 & $33-34$ \\
pH & 7.08 & 7.15 & $7-8.5$ \\
Temperature $\left({ }^{\circ} \mathrm{C}\right)$ & 28.8 & 28.5 & $28-30$ \\
Visibility $(m)$ & 1 & Up to the bottom & 75 \\
$\mathrm{DO}(\mathrm{mg} / \mathrm{L})$ & 3.45 & 0.11 & $>5$ \\
$\mathrm{NH}(\mathrm{mg} / \mathrm{L})$ & 2.5 & 0.000 & 0.3 \\
$\mathrm{~S}^{2-}(\mathrm{mg} / \mathrm{L})$ & 0.000 & 3.6 & 0.01 \\
$\mathrm{NO}_{3}(\mathrm{mg} / \mathrm{L})$ & 2.6 & $\mathrm{~s}$ & 0.008 \\
\hline
\end{tabular}

Source of quality standards: Decree of the State Minister for the Environment, Number 51, Year 2004

Table 2. Biodiversity of microorganism isolates from Karimunjawa and Panjang Island, Central Java, Indonesia

\begin{tabular}{|c|c|c|c|c|c|}
\hline Microorganism & Sampling & Host & Code & Bacteria isolate & Yellow microorganism \\
\hline \multirow[t]{18}{*}{ Bacteria } & \multirow[t]{8}{*}{ Panjang Island } & Sinularia & 19.PP.Sc1 & 6 & 4 \\
\hline & & Sarchophyton & 19.PP.Sc2 & 5 & 2 \\
\hline & & Sarchophyton & 19.PP.Sc3 & 4 & - \\
\hline & & Lobophytum & 19.PP.Sc4 & 3 & 1 \\
\hline & & Lobophytum & 19.PP.Sc5 & 4 & 2 \\
\hline & & Sinularia & 19.PP.Sc6 & 7 & - \\
\hline & & Lobophytum & 19.PP.Sc7 & 3 & 1 \\
\hline & & Subtotal & & 32 & 10 \\
\hline & \multirow{10}{*}{ Karimunjawa Island } & Stereonephthya & KJ-CB-01 & 5 & 1 \\
\hline & & Sinularia & KJ-CB-02 & 2 & - \\
\hline & & Lobophytum & KJ-CB-03 & 3 & 2 \\
\hline & & Xenia & KJ-CB-04 & 3 & 2 \\
\hline & & Sinularia & KJ-CB-05 & 4 & - \\
\hline & & Lobophytum & KJ-CK-01 & 3 & - \\
\hline & & Lobophytum & KJ-CK-02 & 4 & 1 \\
\hline & & Cladiella & KJ-CK-03 & 4 & 1 \\
\hline & & Sarcophyton & KJ-CK-04 & 4 & 2 \\
\hline & & Subtotal & & 32 & 9 \\
\hline \multirow[t]{19}{*}{ Fungi } & \multirow{8}{*}{ Panjang Island } & Sinularia & 19.PP.Sc1 & 3 & 1 \\
\hline & & Sarchophyton & 19.PP.Sc2 & 3 & - \\
\hline & & Sarchophyton & 19.PP.Sc3 & - & - \\
\hline & & Lobophytum & 19.PP.Sc4 & 2 & - \\
\hline & & Lobophytum & 19.PP.Sc5 & 2 & - \\
\hline & & Sinularia & 19.PP.Sc6 & 6 & - \\
\hline & & Lobophytum & 19.PP.Sc7 & 2 & 1 \\
\hline & & Subtotal & & 18 & 2 \\
\hline & \multirow{11}{*}{ Karimunjawa Island } & Stereonephthya & KJ-CB-01 & 2 & - \\
\hline & & Sinularia & KJ-CB-02 & 3 & 1 \\
\hline & & Lobophytum & KJ-CB-03 & 3 & - \\
\hline & & Xenia & KJ-CB-04 & 3 & - \\
\hline & & Sinularia & KJ-CB-05 & - & - \\
\hline & & Lobophytum & KJ-CK-01 & - & - \\
\hline & & Lobophytum & KJ-CK-02 & 2 & 1 \\
\hline & & Cladiella & KJ-CK-03 & 4 & 2 \\
\hline & & Sarcophyton & KJ-CK-04 & 2 & - \\
\hline & & Subtotal & & 19 & 4 \\
\hline & & Total & & 101 & 25 \\
\hline
\end{tabular}




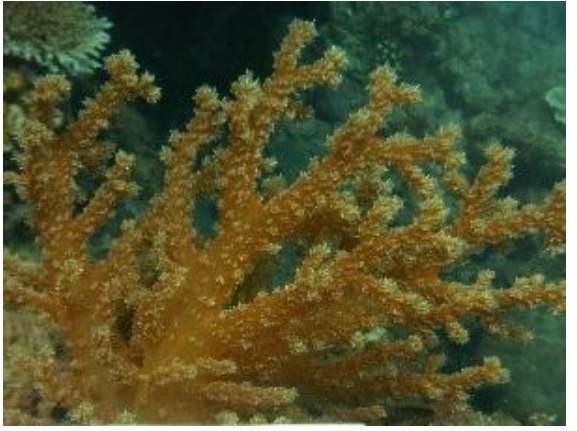

A

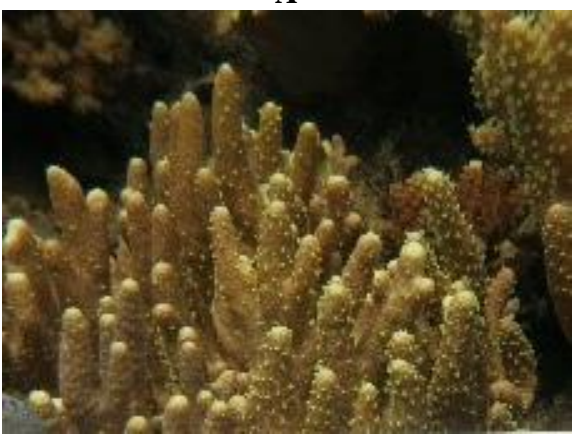

D



B

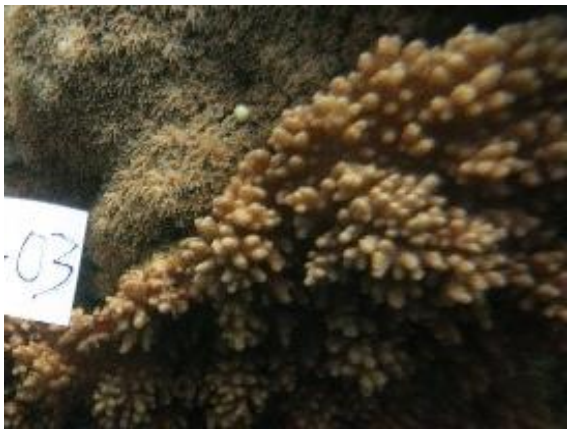

$\mathbf{E}$

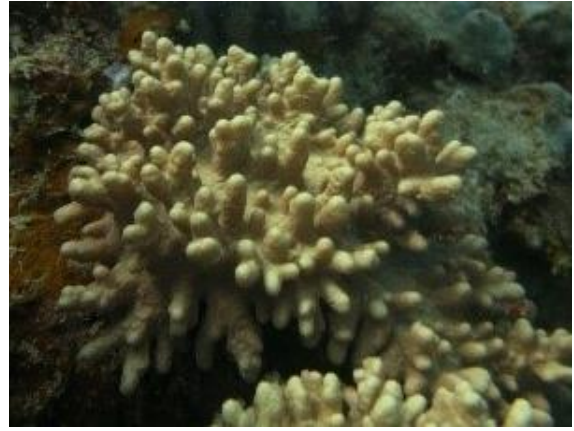

C

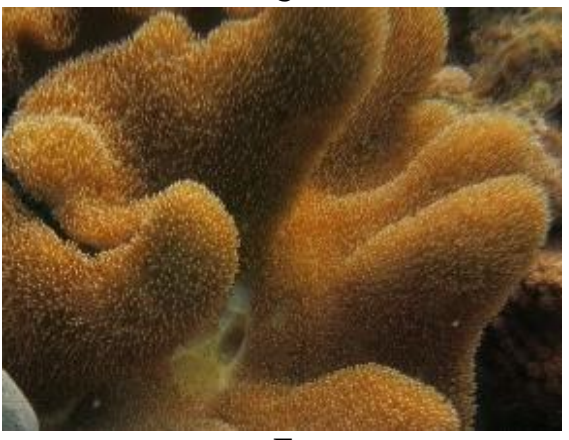

Figure 2. Soft coral samples for microbial isolation. Note: A. Stereonephthya sp., B. Xenia sp., C. Sinularia sp., D. Lobophytum sp., E. Cladiella sp., F. Sarcophyton sp.

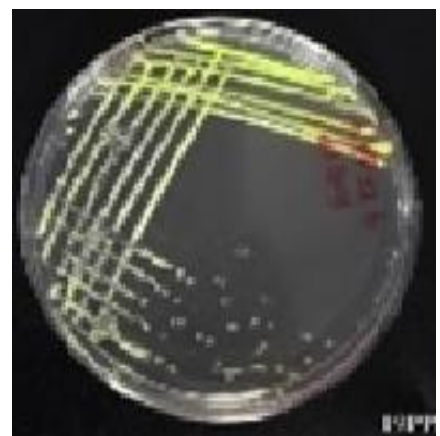

A

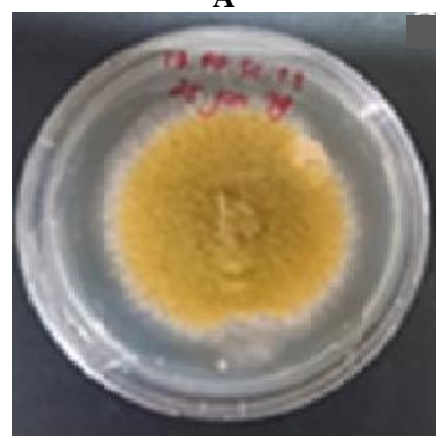

E



B

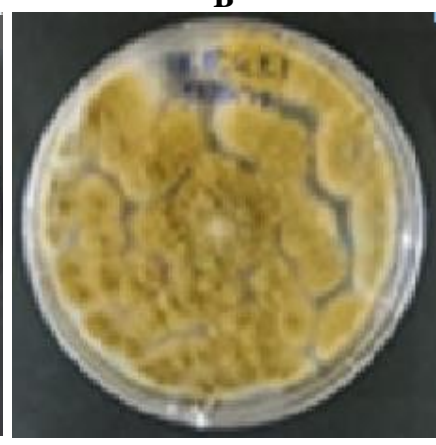

F

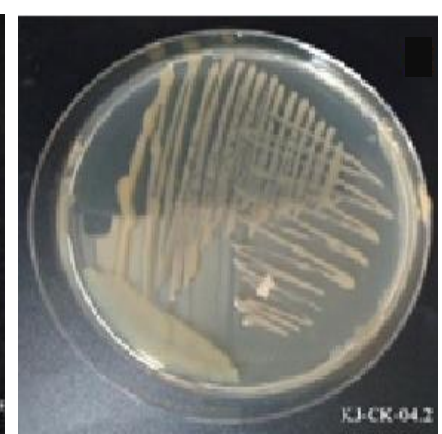

C

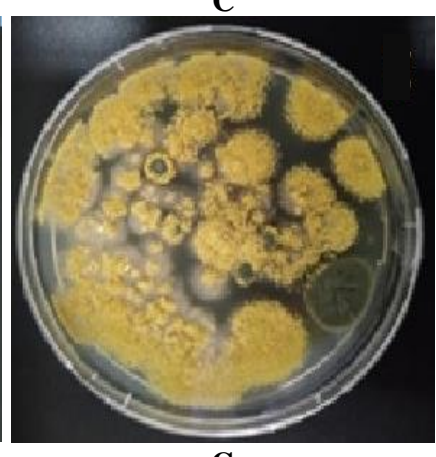

G



D



H

Figure 3. Yellow symbiotic microorganisms from Panjang and Karimunjawa Islands, Central Java, Indonesia. Note: A-B. Bacterial symbionts from Panjang; C-D. Bacterial symbionts from Karimunjawa; E-F. Fungal symbionts from Panjang; G-H. Fungal symbionts from Karimunjawa 


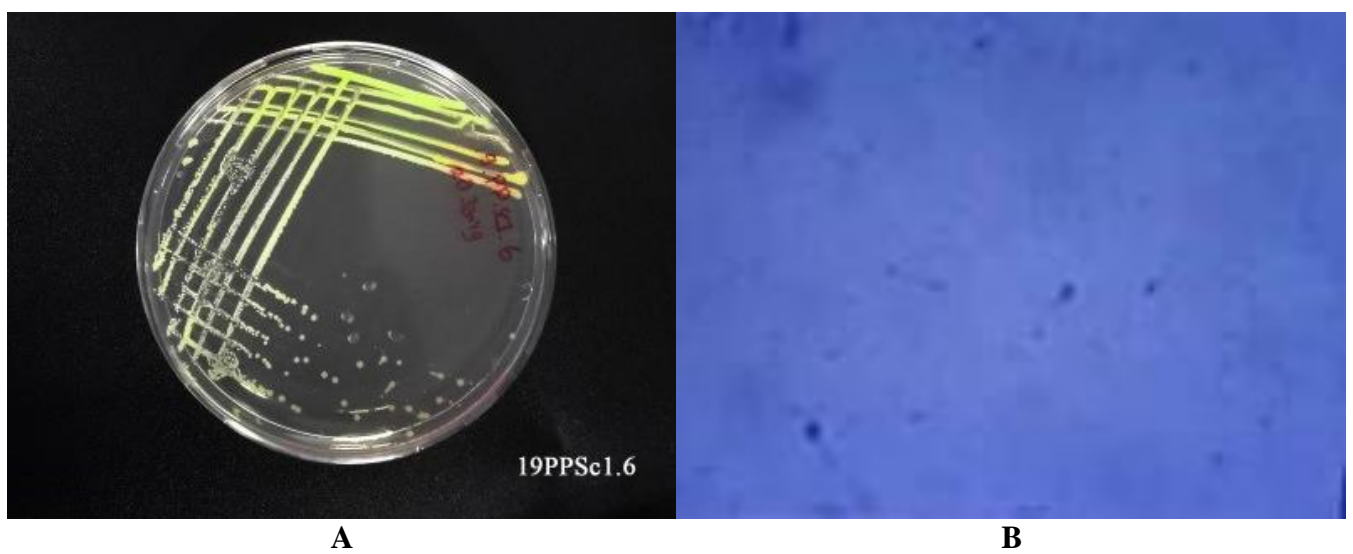

Figure 4. A. Isolate 19. PP.Sc .1.6 and B. Gram staining

Table 3. The antioxidant in \% inhibitory and SPF bioactivity test (concentration of $1000 \mathrm{ppm}$ )

\begin{tabular}{lcccc}
\hline \multicolumn{1}{c}{ Place } & $\begin{array}{c}\text { Micro- } \\
\text { organism } \\
\text { type }\end{array}$ & Bacterial code & $\begin{array}{c}\text { \% inhibitory } \\
(\boldsymbol{\%})\end{array}$ & $\begin{array}{c}\text { SPF } \\
\text { score }\end{array}$ \\
\hline Panjang & Bacteria & 19.PP.Sc 1.3 & 51.97 & 3.27 \\
Island & & 19.PP.Sc 1.4 & 33.62 & 2.36 \\
& & 19.PP.Sc 1.5 & 49.30 & 3.80 \\
& & 19.PP.Sc 1.6 & 77.48 & 6.63 \\
& & 19.PP Sc 2.1 & 31.11 & 2.23 \\
& & 19.PP.Sc 2.5 & 50.91 & 2.56 \\
& & 19.PP.Sc 4.3 & 60.23 & 3.19 \\
& & 19.PP.Sc 5.1 & 50.25 & 2.65 \\
Karimun- & & 19.PP.Sc 5.2 & 41.49 & 3.33 \\
jawa Island & Bacteria & 19.PP.Sc 7.1 & 54.41 & 2.24 \\
& & 19.PP.Sc.11 & 30.35 & 1.93 \\
& & KJ.PP.Sc 7.1 & 33.38 & 2.76 \\
& & KJ-CB-01-4 & 24.87 & 1.59 \\
& & KJ-CB-03-2 & 27.23 & 1.95 \\
& & KJ-CB-04-2 & 15.72 & 0.32 \\
& & KJ-CB-04-3 & 21.03 & 0.53 \\
& & KJ-CK.02-1 & 29.58 & 2.35 \\
& & KJ-CK-03-3 & 19.02 & 3.74 \\
& & KJ-CK-04-1 & 33.25 & 2.78 \\
& & KJ-CK-04-2 & 23.65 & 2.20 \\
& & KJ-CB-02-3 & 26.99 & 2.90 \\
& & KJ-CK-02-2 & 44.15 & 0.66 \\
& & KJ-CK-03-1 & 30.35 & 1.99 \\
& & KJ-CK-03-4 & 31.34 & 0.32 \\
\hline
\end{tabular}

\section{Antioxidant and sun protection factor bioactivity tests}

Furthermore, the extracts obtained from the soft coral symbiotic microorganisms were tested for their bioactivity, i.e., antioxidant activity and SPF. The antioxidant in \% inhibitory and SPF bioactivity test results of the carotenoid extracts are listed in Table 3.

According to the antioxidant activity and SPF values in Table 3, the carotenoid extracts from Panjang Island displayed higher activity than those from Karimunjawa Island. The highest antioxidant activity was found in bacterium isolate 19.PP.Sc1.6 from Panjang Island. The highest SPF value was also observed in the same bacterial extract. The carotenoid extracts from Karimunjawa Island produced an overall inhibition percentage of below 50\% at the same concentration. Thus, the $\mathrm{IC}_{50}$ of the soft coral symbiont carotenoid extracts from Karimunjawa Island was over $1000 \mathrm{ppm}$.

\section{Molecular identification}

Molecular identification was carried out on the microorganism with the highest bioactivity, namely the 19.PP.Sc1.6 bacterium. This strain had a yellow-colored colony, indicating carotenoid production (Figure 4). Phylogenetic analyses based on the 16S rRNA gene showed that strain 19.PP.Sc1.6 formed a tight clade with other species of Virgibacillus (Figure 5).

The initial characterization of the 19.PP.Sc1.6 bacterium was carried out by Gram staining (Figure 2.B). Based on this test, the isolate was assigned to the grampositive bacteria. This genus was a sister group of Oceanobacillus, which is commonly found in marine environments. At the species level, strain 19.PP.Sc1.6 can be genetically identified as Virgibacillus salarius, with $99 \%$ similarity.

\section{Discussion}

Seawater quality measurement

Based on our observations, the seawater quality around Karimunjawa met the established quality standards, except for the nitrate levels. High nitrate levels can be caused by high organic matter input. These organic materials can come from land erosion, household waste, or agricultural waste such as residual fertilization that enters the sea (Farantika et al. 2020). According to Casali et al. (2010), agricultural activities promote runoff, nitrate sedimentation, and phosphate pollution.

In the waters off Panjang Island, several parameters, salinity, brightness, DO, ammonia, and nitrate did not meet the established quality standards. The salinity of the Panjang Island water was slightly lower than that of other marine waters in Indonesia. Based on Farantika et al. (2020), the surface salinity of Indonesian ocean waters averages between $32-34 \%$. The low salinity around Panjang Island could have been influenced by measuring it during the rainy season. Amri et al. (2018) measured salinity variation monthly and showed that seawater has a lower salinity during the rainy season than in dry season. 


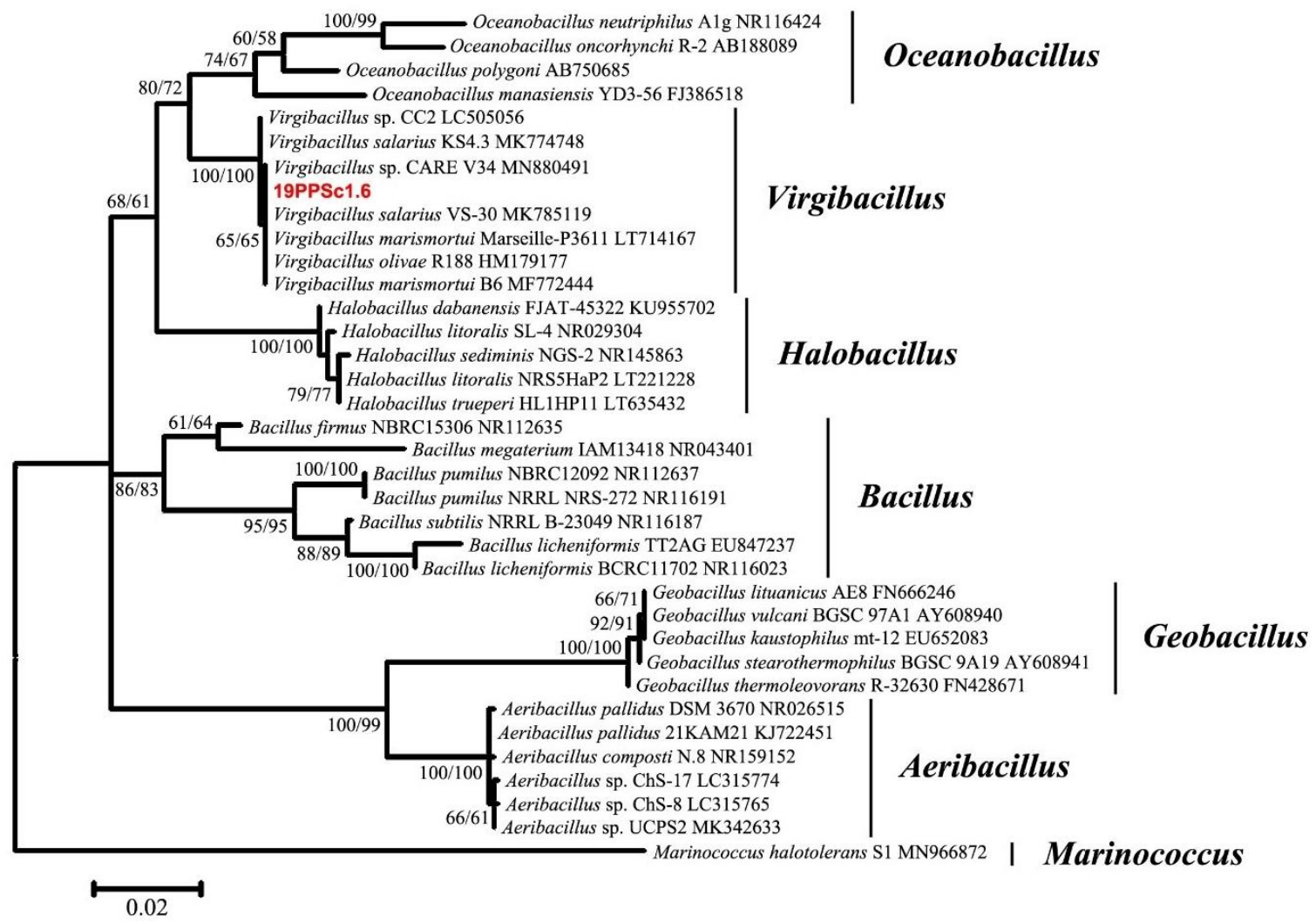

Figure 5. Phylogenetic tree of 19.PP.Sc 1.6 bacteria

The visibility in the Panjang Island waters was relatively low. This is because of a large supply of sediment and particles that dissolved in organic and inorganic materials and transported through runoff flow from the mainland into the sea. This causes high turbidity levels. According to Widiadmoko (2013), the ability of sunlight to penetrate to the bottom of water bodies is influenced by the turbidity of the water. The turbidity of seawater determines the photosynthetic rates of marine life. At high turbidities, photosynthesis is hampered because the sun's rays cannot penetrate easily.

The DO levels in the Panjang Island waters did not meet the established quality standards. The DO content in water is related to the level of pollution, type of waste, and amount of organic material in the water. The ammonia and nitrate levels in the Panjang Island waters also failed to comply with the established quality standards. High levels of ammonia is a characteristic of organic pollution (Widiadmoko 2013), while high nitrate levels can endanger aquatic organisms.

\section{Soft corals and symbiotic microorganisms}

The sampling results show in table 2 that the soft corals at Karimunjawa Island are more abundant and varied than those at Panjang Island. The presence and abundance of species are related to physical, chemical, and biological environmental conditions and these factors affect the physiology of soft corals (Zainuddin et al. 2013). Based on the water quality measurements, the water surrounding Karimunjawa Island meets the specified quality standards better than that at Panjang Island. The diversity in an ecosystem is determined by several factors, such as time, spatial heterogeneity, competition, predation, environmental stability, and productivity. Of these, environmental stability and competition are the most influential. Changes in environmental conditions greatly affect individuals in maintaining their lives (Manuputty 2016).

Microorganism carotenoid production can be identified by the colors produced (yellow-orange to red). It can also be confirmed by the spectral patterns of carotenoid extracts (Nugraheni et al. 2010; Zaghdoudi et al. 2017). Carotenoids show characteristic absorption at wavelengths of 300-600 nm (Rodriguez-Amaya and Kimura 2004). All the yellow symbiotic microorganism extracts showed absorption at these wavelengths and produced the same pattern as carotenoids (Figure 3 ).

\section{Antioxidant and sun protection factor bioactivity tests}

The water quality at Panjang Island was not ideal for soft coral growth, triggering carotenoid production. Carotenoids absorb light energy for photosynthesis, provide specific coloration patterns in plants and animals, screen from excessive light and spectral filtering, and defend egg proteins from proteases in some invertebrates. Moreover, the direct carotenoid derivative, retinal, acts as a 
visual pigment in all animals and as a chromophore in bacteriorhodopsin photosynthesis, and retinoic acid in animals and abscisic acid in plants serve as hormones (Kirti et al. 2014). The production of carotenoids as secondary metabolites is a mechanism used to maintain the fitness of an organism faced with environmental changes detrimental to their survival (Ramakrishna and Ravishankar 2011; Isah 2019). The same organism can produce different secondary metabolites depending on environmental stresses. Stressful conditions trigger the formation of secondary metabolites, one of which is carotenoids (Radušiene et al. 2012).

Marine organisms are often exposed to abiotic environmental pressures, such as changes in light intensity, salinity, DO, and chemicals. For proper growth, marine organisms require specific amounts of abiotic components. An excess or deficiency of abiotic components will trigger variations in the biosynthesis of secondary metabolites (Verma and Shukla 2015). Carotenoids, as secondary metabolites, play an important role in the adaptation of organisms to stressful environments. Carotenoids have antioxidant properties and act as the first defense against oxidative stress. Stressful environmental conditions produce reactive oxygen species (Ashraf et al. 2018), which are free radicals in the form of oxygen and its derivatives and are highly reactive (Phaniendra et al. 2015). Oxidative damage is caused by the unpaired electrons of reactive oxygen species. To prevent such damage, an organism can produce antioxidants, such as carotenoids (Young and Lowe 2018). Carotenoid compounds first formed to function as free radical reducers (Khoo et al. 2011; Kumar et al. 2016b).

\section{Molecular identification}

$V$. salarius is a gram-positive bacteria were isolated from a salt crust in the Gharsa salt lake in Tunisia (Hua et al. 2008). From the marine environment, Kusmita et al. (2017) also found the carotenoid producing bacteria, $V$. salarius in Sarcophyton sp. hosts. Because of their pigment production abilities, $V$. salarius may become a potential resource for natural pigments with various biological properties. However, further study, particularly regarding pigment purification and identification, is required.

\section{ACKNOWLEDGEMENTS}

The author wish to acknowledge the Balai Taman Nasional Karimunjawa for the research permit with number 1277/T.34/TU/SIMAKSI/04/2019. This research was partly funded by the Ministry of Research, Technology, and Higher Education, Indonesia under the Program Beasiswa Pendidikan Pascasarjana Dalam Negeri (BPPDN) decree number 2903.9/D3/PG/2017 and Hibah Disertasi Doctor number 225-16/UN7/6.1/PP/2020

\section{REFERENCES}

Amri K, Muchlizar, Ma'mun A. 2018. Variasi bulanan salinitas, pH, dan oksigen terlarut di perairan estuari bengkalis. Majalah Ilmiah Globe 20 (2): 57-66. DOI: 10.24895/MIG.2018.20-2.645. [Indonesian]
Ashraf MA, Iqbal M, Rasheed R, Hussain I, Riaz M, Arif MS. 2018. Environmental stress and secondary metabolites in plants: An Overview. In: Ahmad P, Ahanger MA, Singh VP, Tripathi DK, Alam $\mathrm{P}$, Alyemeni MN (eds). Plant Metabolites and Regulation Under Environmental Stress. Elsevier Inc., United Kingdom.

Casali JR, Gimenez J, Diez J, Alvarez-Mazos J, de Lersundi DV, Goni M, Campo MA, Chahor Y, Gastesi R, Lopez J. 2010. Sediment production and water quality of watersheds with contrasting land use in Navarre (Spain). Agric Water Manag 97: 1683-1694. DOI: 10.1016/j.agwat.2010.05.024

Decree of the State Minister for the Environment Number 51 Year 2004 about Sea Water Quality Standard.

Farantika R, Putro SP, Hadi M, Triarso I. 2020. Study on water quality physical-chemical parameters aquaculture areas in Menjangan Besar Island, Kepulauan Karimunjawa, Jepara, Indonesia. J Phys Conf Ser 1524: 012136. DOI:10.1088/1742-6596/1524/1/012136.

Galasso C, Corinaldesi C, Sansone C. 2017. Carotenoids from marine organisms: Biological functions and industrial applications. Antioxid 6: 96. DOI: 10.3390/antiox6040096.

Hamuna B, Tanjung, Suwito RHR, Maury HK, Alianto. 2018. Kajian kualitas air laut dan indeks pencemaran berdasarkan parameter fisikakimia di perairan distrik Depapre Jayapura. Jurnal Ilmu Kelautan 16 (1): 35-43. DOI: 10.14710/jil.16.1.35-43. [Indonesian].

Hua NP, Hamza-Chaffai A, Vreeland RH, Isoda H, Naganuma T. 2008. Virgibacillus salarius sp. nov., a halophilic bacterium isolated from a Saharan salt lake. Intl J Syst Evolut Microbiol 58 (10): 24092414. DOI: $10.1099 / \mathrm{ijs} .0 .65693-0$

Ibrahim HAH. 2012. Antibacterial carotenoids of three Holothuria species in Hurghada, Egypt. Egypt J Aquat Res 38: 185-194. DOI: 10.1016/j.ejar.2013.01.004

Isah T. 2019. Stress and defense responses in plant secondary metabolites production. Biol Res 52: 39. DOI: 10.1186/s40659-019-0246-3

Kirti K, Amita S, Priti S, Kumar AM, Jyoti S. 2014. Colorful world of microbes: Carotenoids and their applications. Adv Biol 2014: 837891. DOI: $10.1155 / 2014 / 837891$

Kjer J, Debbab A, Aly AH, and Proksch P. 2010. Methods for isolation of marine-derived endophytic fungi and their bioactive secondary products. Nat Protoc 5 (3): 479-490. DOI: 10.1038/nprot.2009.223

Khoo HE, Prasad KN, Kong KW, Jiang Y, Ismail A. 2011. Carotenoids and their isomers: Color pigments in fruits and vegetables. Mol 16: 1710-1738. DOI: 10.3390/molecules16021710.

Kumar S, Stecher G, Tamura K. 2016a. MEGA7: Molecular evolutionary genetics analysis version 7.0 for bigger datasets. Mol Biol Evol 33: 1870-1874. DOI: $10.1093 / \mathrm{molbev} / \mathrm{msw} 054$.

Kumar SA, Chaudhuri S, Dutta D. 2016b. Antioxidant efficacy of carotenoid extract from bacterial strain Kocuria marina DAGII. Mater Today Proc 3: 3427-3433. DOI: 10.1016/j.matpr.2016.10.023.

Kusmita L, Mutiara EV, Nuryadi H, Pratama PA, Wiguna AS, Radjasa OK. 2017. Characterization of carotenoid pigments from bacterial symbionts of soft-coral Sarcophyton sp. from North Java Sea. Intl Aquat Res 9: 61-69. DOI: 10.1007/s40071-017-0157-2.

Manuputty AEW. 2016. The common soft corals (Octocorallia: Alcyonacea) in East Biak Waters. Oseanologi dan Limnologi di Indonesia 1 (2): 47-59. DOI: 10.14203/oldi.2016.v1i2.23.

Maoka T. 2011. Carotenoids in marine animals. Mar Drugs 9: 278-293. DOI: $10.3390 / \mathrm{md} 9020278$.

Mbanga L, Mulenga M, Mpiana PT, Bokolo K, Mumbwa M, Mvingu K. 2014. Determination of Sun Protection Factor (SPF) of somebody creams and lotions marketed in Kinshasa by ultraviolet spectrophotometry. Intl J Adv Res Chem Sci 1 (8): 7-13.

Murti DB, Susanto A, Radjasa OK, Rondonuwu FS. 2016. Pigments characterization and molecular identification of bacterial symbionts of Brown Algae Padina sp. collected from Karimunjawa Island. Indones J Mar Sci 21: 59-64. DOI: 10.14710/ik.ijms.21.2.59-64.

Nugraheni SA, Khoeri MM, Kusmita L, Widyastuti Y, Radjasa OK. 2010 Characterization of carotenoid pigments from bacterial symbionts of seagrass Thalassia hemprichii. J Coast Dev 14 (1): 51-60.

Phaniendra A, Jestadi DB, Periyasamy L. 2015. Free radicals: properties, sources, targets, and their implication in various diseases. Indian $\mathrm{J}$ Clin Biochem 30 (1): 11-26. DOI: 10.1007/s12291-014-0446-0

Puspasari F, Nurachman Z, Noer AA, Radjasa OK, van der Maarel MJEC, Natalia D. 2011. Characteristics of raw starch degrading $\alpha$-amylase from Bacillus aquimaris MKSC 6.2 associated with soft coral Sinularia sp. Starch 63: 462-467. DOI: 10.1002/star.201000127.

Radjasa OK, Vaske YM, Navarro G, Vervoort HC, Tenney K, Linington RG, Crews P. 2011. Highlights of marine invertebrate-derived 
biosynthetic products: Their biomedical potential and possible production by microbial associates. Bioorg Med Chem 19: 66586674. DOI: 10.1016/j.bmc.2011.07.017.

Radjasa OK, Khoeri MM, Darusallam CC, Trimasanto H, Sudoyo H. 2013. Bacterial symbionts of reef invertebrates: Screening for antipathogenic bacteria activity. Biodiversitas 14: 80-86. DOI: 10.1080/14888386.2013.774937.

Radušiene J, Karpaviciene B, Stanius Ž. 2012. Effect of external and internal factors on secondary metabolites accumulation in St. John's worth. Bot Lith 18 (2): 101-108. DOI: 10.2478/v10279-012-0012-8

Ramakrishna A, Ravishankar GA. 2011. Influence of abiotic stress signals on secondary metabolite in plants. Plant Signal Behav 6 (11): 1720 1731. DOI: $10.4161 /$ psb.6.11.17613.

Riccioni G, D’Orazio N, Franceschelli S, Speranza L. 2011. Marine carotenoids and cardiovascular risk markers. Mar Drugs 9: 11661175. DOI: $10.3390 / \mathrm{md} 9071166$

Rodriguez-Amaya DB, Kimura M. 2004. HarvestPlus Handbook for Carotenoid Analysis. International Food Policy Research Institute (IFPRI) and International Center for Tropical Agriculture (CIAT), Washington, DC.

Sabdono A, Sawonua PH, Kartika AGD, Amelia JM, Radjasa OK. 2015. Coral diseases in Panjang Island, Java Sea: Diversity of antipathogenic bacterial coral symbionts. Proc Chem 14: 15-21. DOI: 10.1016/J.PROCHE.2015.03.004.

Shetty MJ, Geethalekshmi PR, Mini C. 2017. Natural pigments as potential food colourants: A Review. Trends Biosci 10 (21): 4057 4064.

Sibero MT, Bachtiarini TU, Trianto A, Lupita AH, Sari DP, Igarashi Y, Harunari E, Sharma AR, Radjasa OK, Sabdono A. 2019.
Characterization of a yellow pigmented coral-associated bacterium exhibiting anti-Bacterial Activity Against Multidrug-Resistant (MDR) Organism. Egypt J Aquat Res 45: 81-87. DOI: 10.1016/j.ejar.2018.11.007.

Verma N, Shukla S. 2015. Impact of various factors responsible for fluctuation in plant secondary metabolites. J Appl Res Med Aromat Plants 2 (4): 105-113. DOI: 10.1016/j.jarmap.2015.09.002.

Vilchez C, Forjan E, Cuaresma M, Bédmar F, Garbayo I, Vega JM. 2011. Marine carotenoids: Biological functions and commercial applications. Mar Drugs 9 (3): 319-333. DOI: 10.3390/md9030319.

Widiadmoko W. 2013. Pemantauan kualitas air secara fisika dan kimia di perairan Teluk Hurun. Balai Besar Pengembangan Budidaya Laut (BBPBL) Lampung, Bandar Lampung. [Indonesian]

Yang L, Wen KS, Ruan X, Zhao YX, Wei F, Wang Q. 2018. Response of plant secondary metabolites to environmental factors. Mol 23 (4): 762. DOI: $10.3390 /$ molecules23040762.

Young AJ, Lowe GL. 2018. Carotenoids-antioxidant properties. Antioxid (Basel) 7 (2): 28. DOI: 10.3390/antiox7020028.

Zaghdoudi K, Ngomo O, Vanderesse R, Arnoux P, Myrzakhmetov B, Frochot C, Guiavarc'h Y. 2017. Extraction, identification and photophysical characterization of Persimmon (Diospyros kaki L.) Carotenoids. Foods 6 (1): 4. DOI: 10.3390/foods6010004.

Zainuddin M, Ambariyanto, Widowati I. 2013. Kajian kualitas perairan Jepara terhadap kelimpahan dan senyawa bioaktif antimikrobia ekstrak Seaweed Spesies Sargassaceae (Phaeophyta, Fucales), Prosiding Seminar Nasional III. Fakultas Perikanan dan Ilmu Kelautan, Diponegoro University, Semarang, 31 August 2013. [Indonesian]. 